\title{
OUR DAILY SOIL
}

Ivica Kisić

https://doi.org/10.32701/dp.21.1.4

The definition of sustainable management of soil should be interpreted in the broader sense, not only in the perspective of agricultural soil (Basic 2017). Elementary, the soil is a medium for growing plants. The supply of water, air, and nutrients are prerequisites for photosynthesis, i.e. the production of organic matter and the provision of food, fodder crops, renewable energy and raw materials necessary for the survival of human civilisations. This is why agriculture and forestry appear to be primary industries directly dependent on the soil. The soil is the basis of the biodiversity of the wildlife living above and below the surface (Basic, 2013). Cycles of some elements (C, N, P, S, etc.) also have stages that develop in the soil, so the soil is an integral part of many ecosystems. The climate regulation role of the soil has great importance. Precisely, it is a central link in the biotransformation chain of organic carbon. It affects the content and total amount of $\mathrm{CO} 2$ and other gases that cause the "greenhouse effect" (Lal 2014). The hydrological role of soil is vital in the hydrological cycle because vast amounts of water is stored in the soils pores and colloids (humus, clay). The soil is a universal purifier (filter) and protects the water from various contaminants that are in the soil (Kisic et al. 2018).

In addition to the production and regulation roles, which are the most important, the soil has other functions. The soil is the base for technical, industrial and economic structures (housing, industry, transport, sport, recreation, landfill). Soil is a source of geogenic energy and raw materials (sand, gravel, clay) and drinking water. Soil shapes the landscape, altered by either natural or anthropogenic sources. At the same time, the soil is a valuable natural - palaeontological and archaeological treasury. Proper use of the soil represents temporally and spatially coordinated use of all described roles of soil, which are not always complementary, sometimes intertwined and mutually exclusive (Blasi et al. 2016). The vital task of the science on the soil is to know all the roles described and to protect the soil in a condition that enables these roles to be implemented.

* Prof Ivica Kisić, PhD, Department of General Agronomy, Faculty of Agriculture, University of Zagreb. Email: ikisic@agr.hr 


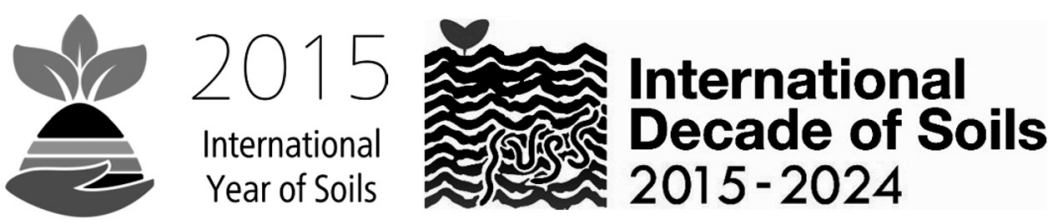

Figures 1 and 2 The international symbol of the year and decade of the soil

\section{Research results}

According to all relevant prognosis, the population of Earth is expected to increase from the current 7.7 to 8 billion by 2023, at the latest. It is important to emphasise that there were only 3 billion people on planet Earth 50 years ago. By 2025, there will be nearly 40 cities on the Planet that will have more than 10 million inhabitants. The basic task of the soil in agriculture will be to provide sufficient quantities of food and drinking water to the growing population, as mentioned above (Balmford et al. 2018). The objectives that will be addressed in soil management can be summarised, as follows:

Globally:

- Maintaining the balance of the circulation of matter and energy in the soil as part of the overall environment and biodiversity,

- Protection of large areas where human activity has not significantly affected the dynamic balance of the habitat,

- At the beginning of the second decade of this century, the urban population became more massive than the rural population for the first time in the history of human civilisation.

In rural areas:

- Maintaining soil quality for the production of adequate biomass in an area,

- Protection of soil's possibility to infiltrate and retain water in soil mass and its biological activity,

- Increasing the amount of carbon stock in soils and vegetation,

- Providing habitats for natural vegetation and animals within agricultural landscapes,

- Monitoring soil nutrient calculations and maintaining soil fertility through fertilisation.

In urban areas:

- Minimalizing soil cover and allowing natural infiltration of precipitation, biological activity in the soil and gas exchange,

- Conservation of habitats for plants, animals and food production surfaces in urban landscapes,

- Harmonisation of nutrient circulation - nutrient intake and discharge from urban areas is desirable to be carried out in a balanced manner, preferably in the same region, 
- Reducing the deposition of toxic substances in soil, water, and air, and avoiding the accumulation of persistent substances in soil and sediments.

An important area, that is being increasingly addressed by modern soil science, is the impact of soil management on global climate change (Lal 2004). Extremes that have been occurring over the last two decades (low/ high temperatures or periods with no rainfall alternating with extreme precipitation in a very short period) are something that we have to get used to. The fact is that the climate is changing, that years 2000, 2003, 2006, 2011 and 2013 were extremely dry but at the same time during 2002, 2010, 2012 and 2014 we had problems with floods (Kisic 2015). During 2017 an extremely high number of open space fires was recorded, nearly seven thousand. In the 2018 fire season, there were 68\% fewer fires and 96\% less burned area compared to 2017, or 39\% fewer fires and 90\% less burned area relative to the ten-year average (Kisic 2019). Although the Croatian Goverment will boast that more effective measures have been taken to prevent fires, we believe that the main reason for the lower number of fires in 2018 is the weather conditions which include the average lower temperatures and higher rainfall during the year compared to 2017.

Human and nature must adapt to all this. However, the biggest problem is that we are going towards times where there will be more and more extremes, from extremely low and high temperatures on one side to extremely low and high precipitation on the other. Frosts will appear in months and periods when this was not common. Stern (2006) states that climate damage over the next 30 years on planet Earth is estimated at \$ 74, 000 billion.

For these reasons, more and more questions are being raised in scientific circles, to which even the scientists themselves do not have a clear answer (Clark and Tilman 2017, Cowie et al. 2018). The problem is that these changes happen extremely quickly and are almost impossible to answer. Here are just some of the questions: The reciprocal impact of climate change and soil management? What are the prospects for increasing or decreasing soil fertility in an area affected by climate change? What are the real options for increasing carbon stock in the soil to mitigate climate change? Opportunities to live in cities during the summer months with the use of all possible air conditioners at extremely high summer temperatures (Figure 3). As mentioned above, there is an increasing number of urban population compared to rural.

The impact of humans on the degradation of soil fertility globally is best shown in the GLASOD (Global Assessment of Soil Degradation)' ${ }^{1}$, according

1 More information at https://www.isric.org/index.php/projects/global-assessment-humaninduced-soil-degradation-glasod 
to which soil degradation occurred on $36 \%$ of the surface used by the human population on the planet. The degradation generally means a reduction in the natural ability of soil to perform its roles in the ecosystem (Gomiero 2016; Kanianska 2016, Wiesmeier et al. 2019). The potential source of pollution is shown in Figure 4, while soil degradation/damage modes are shown in Table 1. Of the total 13.340 million hectares of land that is not covered by ice, 3.030 million are potentially arable land. The arable land and permanent crops now occupy 1.475 million hectares; pasture lands 3.200 million hectares, and forests and wetlands 4.050 million hectares. Of the remaining 4.414 million hectares, about 200 million hectares are occupied by cities and infrastructure. The reduction of arable land per capita 0.28 ha in 1990 to 0.17 ha by 2025, provided that prognosis is made of population increase on Earth and changes in urban/rural population (Pereira et al. 2018).

Soil suitability for agriculture is limited by soil quality, climate and relief (Virto et al. 2015). The global strategy for the future development of agriculture relies precisely on optimal use of soil, which involves the application of high technology in the best agricultural soils, to protect soil areas less suitable for agriculture and natural vegetation and animal species (Varallyay 2007). However, such, more or less intensive technology must necessarily comply with the requirements for sustainable agriculture and sustainable soil management (Montgomery 2012; Sheibani and Ahangar 2013).

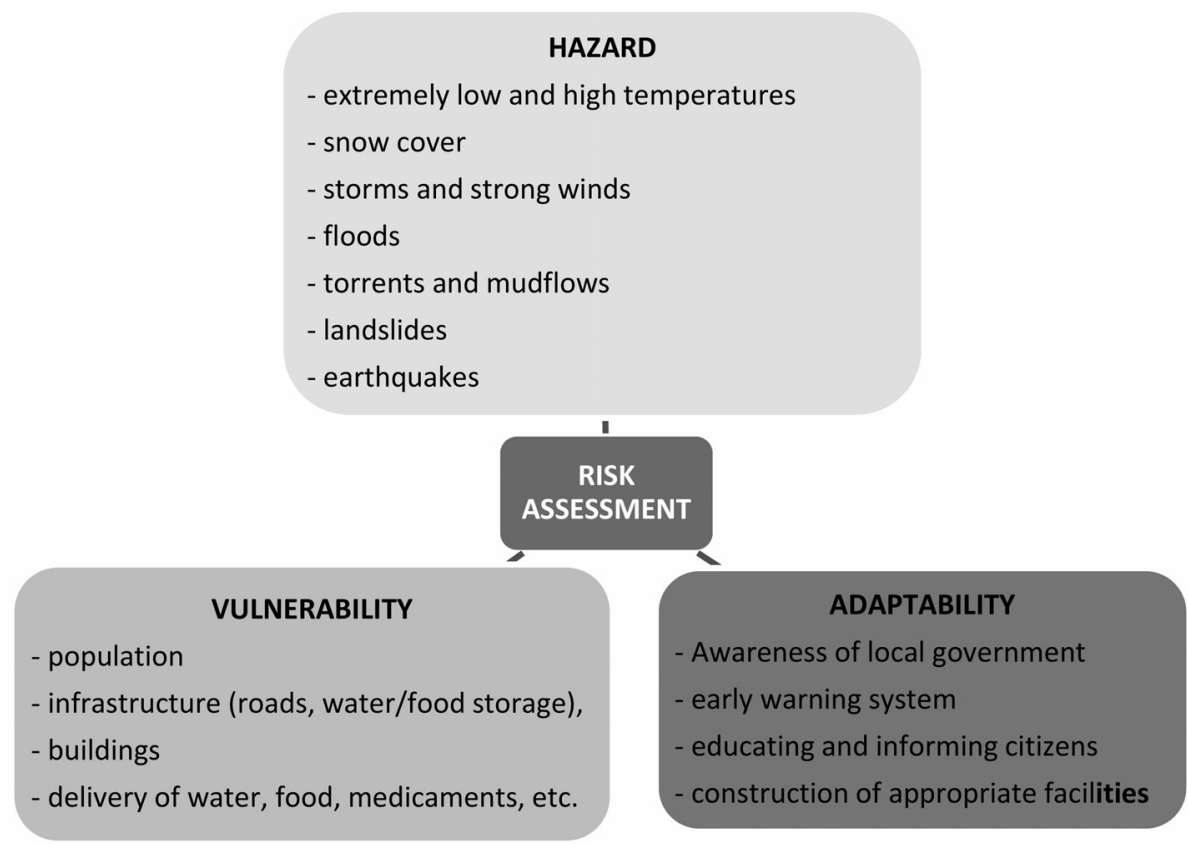

Figure 3. Risk assessment of urban living. Source: Carter et al. 2015, adjusted 
Defining sustainability indicators and their limit values was the one of the most significant challenges of soil science at the beginning of the new millennium. The ground indicators of sustainability of practised soil management are physical (structure, porosity, water and air capacity, etc.), chemical (soil reaction, organic matter content, cation exchange capacity, macro and microelement content, heavy metal content, etc.) and biological characteristic of soil (number and type of micro-organisms, soil biology earthworms). The main advantage of these indicators is the ability to quantify them. For each of the above indicators, it is necessary to set limit values following the appropriate categories: high suitability, moderate suitability, partially suitable and unfit soil for a particular form of use. The process of designating sustainable management as a horizontal element includes Field research $\rightarrow$ Databases $\rightarrow$ Geographic information system $\rightarrow$ Use of computer models $\rightarrow$ Recommendations for sustainable soil management.

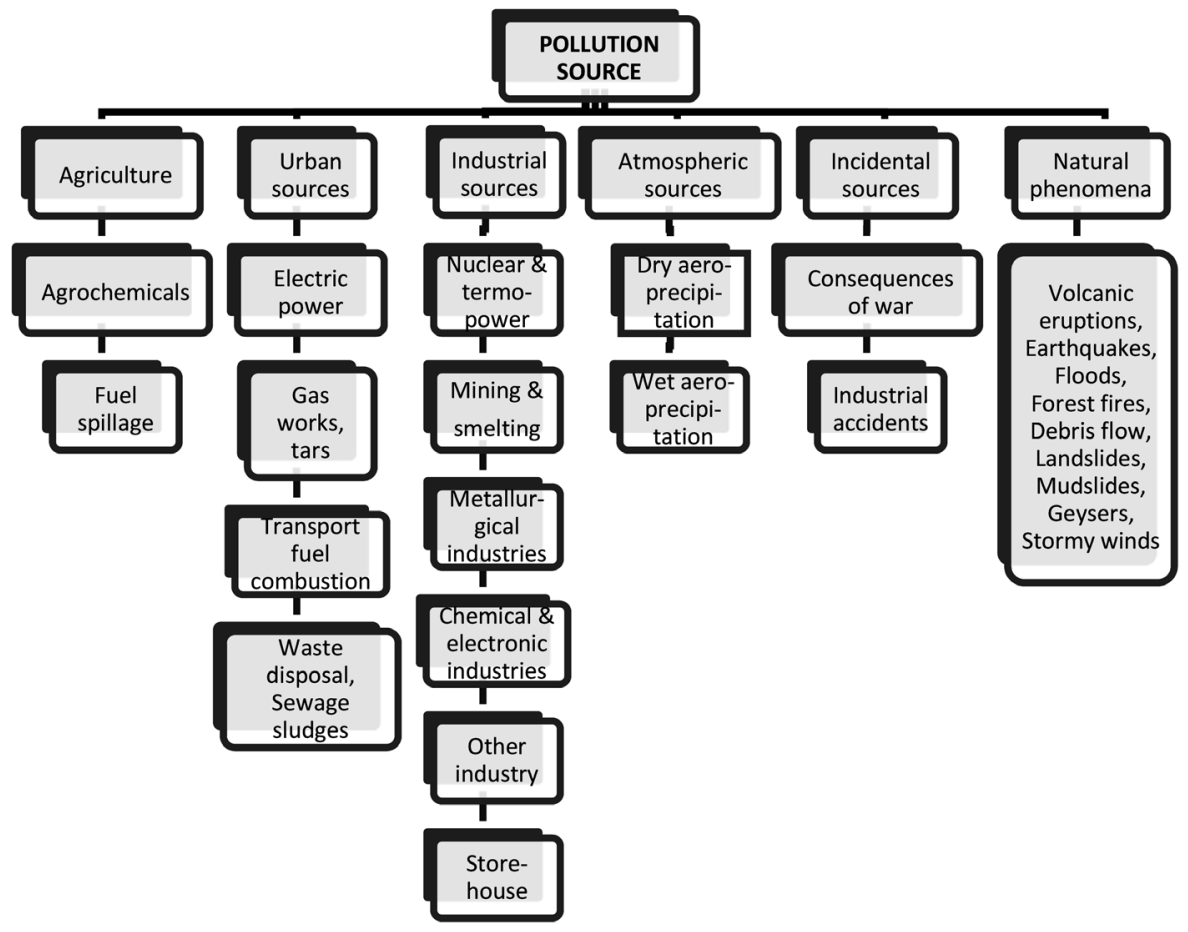

Figure 4. Origin of soil pollution

Source: Mirsal 2008, adjusted

Based on the database, it is necessary to set priorities for further research towards updating existing and collecting new data, following the requirement for defining sustainable land use in any area. The concept of evaluating soil sustainability can be presented by these indicators, as follows: 
- Sustainability is evaluated by accurately and precisely defined use of the soil,

- Sustainability evaluation is done for a specific soil surface,

- Sustainability evaluation is a multidisciplinary process,

- For a particular area, the evaluation is carried out under economic and social conditions,

- Sustainability is assessed by a time period,

- The soil condition and procedures in the soil, conditioned by the existing use, must be precisely defined before defining recommendations for sustainable soil management,

- The evaluation is based on the results of scientific work, as well as scientific methods established by indicators of sustainability and their limit values,

- The introduction of new or modified soil management methods is first carried out at research facilities so that any change can be analysed in detail.

Soil protection against degradation of physical, chemical and biological fertility is a priority in future research (Sheibani and Ahangar 2013). The essential procedures that challenge the sustainability of soil management are soil cultivation, fertilisation and plant protection (Kisic 2014). The key question is certainly how to adapt the cultivation and fertilisation measures and crop protection so that they are more efficient, while at the same time meeting the criteria of sustainable soil management (Sklenicka et al. 2015). By utilising the results of scientific work, efficient effects can be achieved in the sense of reducing costs while maintaining a satisfactory level of intensity in crop cultivation (Dudeja and Singh 2017).

The process of knowledge transfers and new technologies to end-users is one of the pillars of future development, whereby a link between scientific institutions, ministries, advisory services, and farmers should be established. The overall impact of agriculture on the soil is best evaluated based on indicators to regular agricultural activities. Indicators of production sustainability include:

1. Calculation of nutrients,

2. Use of pesticides,

3. Crop yields,

4. Management of organic and mineral fertilisers,

5. The types and methods of diseases, pests and weeds control,

6. Methods of soil cultivation,

7. Ground and surface water pollution,

8. Greenhouse gas emissions,

9. The whole economy management. 
Table 1. Classification of soil damage

\begin{tabular}{|c|c|c|c|}
\hline $\begin{array}{l}\text { DEGREE OF } \\
\text { DAMAGE }\end{array}$ & TYPE OF DAMAGE & $\begin{array}{c}\text { DAMAGE } \\
\text { PROCESSES }\end{array}$ & CONSEQUENCES \\
\hline \begin{tabular}{|l} 
I.SLIGHT \\
EASY TO RENEW \\
(REVERSIBLE)
\end{tabular} & $\begin{array}{l}\text { SOIL } \\
\text { DEGRADATION } \\
\text { IN INTENSIVE } \\
\text { PRODUCTION }\end{array}$ & $\begin{array}{l}\text { 1.1. Degradation } \\
\text { of soil physical } \\
\text { characteristics } \\
\text { 1.2. Degradation } \\
\text { of chemical } \\
\text { characteristics } \\
\text { 1.3. Degradation } \\
\text { of soil biological } \\
\text { characteristics } \\
\text { 1.4.Degradation by } \\
\text { hydro-melioration }\end{array}$ & $\begin{array}{l}\text { - Anthropogenic soil } \\
\text { compaction } \\
\text { - Disturbance of the } \\
\text { air conditions } \\
\text { - Higher energy } \\
\text { consumption for } \\
\text { tillage } \\
\text { - Acidification and } \\
\text { salinisation } \\
\text { - Phototoxic effects } \\
\text { - Reduced } \\
\text { biodiversity } \\
\text { - Disturbed } \\
\text { microflora ratio } \\
\text { - Soil infection } \\
\end{array}$ \\
\hline $\begin{array}{l}\text { II. MODERATE } \\
\text { HARDLY } \\
\text { RENEWABLE } \\
\text { (CONDITIONALLY } \\
\text { REVERSIBLE) }\end{array}$ & $\begin{array}{l}\text { POLLUTION - } \\
\text { CONTAMINATION }\end{array}$ & $\begin{array}{l}\text { 2.1. Heavy metals } \\
\text { and other toxic } \\
\text { elements } \\
\text { 2.2. Pesticide } \\
\text { residues and PAHs } \\
\text { 2.3. Petrochemicals } \\
\text { in soil } \\
\text { 2.4. Radionuclides } \\
\text { 2.5. Emission } \\
\text { acidification of } \\
\text { soils }\end{array}$ & $\begin{array}{l}\text { - Useless food } \\
\text { due to mutagenic, } \\
\text { carcinogenic or } \\
\text { teratogenic treatment } \\
\text { - Depression of plant } \\
\text { growth } \\
\text { - Phytotoxic effects } \\
\text { - Endangered other } \\
\text { ecosystems }\end{array}$ \\
\hline \begin{tabular}{|l} 
III. HEAVILY \\
NONRENEWABLE \\
(IRREVERSIBLE)
\end{tabular} & $\begin{array}{l}\text { DISPLACEMENT - } \\
\text { TRANSLOCATION }\end{array}$ & $\begin{array}{l}\text { 3.1. Water and wind } \\
\text { erosion } \\
\text { 3.2. The } \\
\text { exploitation of } \\
\text { stone, gravel and } \\
\text { other building } \\
\text { materials } \\
\text { 3.3. Relocation of } \\
\text { soil to fruits } \\
\text { 3.4. Soil pots } \\
\text { 3.5. Covering with } \\
\text { garbage, industrial } \\
\text { waste, and ash } \\
\text { 3.6. Covering with } \\
\text { other soil } \\
\text { 3.7. Soil damaged } \\
\text { by the forest fire }\end{array}$ & $\begin{array}{l}\text { - Loss of part of } \\
\text { the soil or the whole } \\
\text { profile } \\
\text { - Change of profile } \\
\text { stratigraphy } \\
\text { - Reduction of } \\
\text { production areas } \\
\text { - Interference with } \\
\text { soil tillage } \\
\text { - Heterogeneity of } \\
\text { soil cover } \\
\text { - Increased } \\
\text { production costs } \\
\text { - Reduced yield } \\
\text { — Endangered other } \\
\text { ecosystems } \\
\text { - Loss of production } \\
\text { area }\end{array}$ \\
\hline $\begin{array}{l}\text { IV. IRRETRIEVABLE } \\
\text { (PERMANENT LOSS } \\
\text { OF SOIL) }\end{array}$ & ADAPTATION & $\begin{array}{l}\text { 4.1. Construction of } \\
\text { urban areas } \\
\text { 4.2. Industrial, } \\
\text { energy facilities, } \\
\text { roads, airports } \\
\text { 4.3. Hydro } \\
\text { accumulations }\end{array}$ & $\begin{array}{l}\text { - Reduced total } \\
\text { production area }\end{array}$ \\
\hline
\end{tabular}

Source: Basic 1994 


\section{Conclusion}

Sustainable soil management is an imperative for the agriculture development in any area of the planet Earth so that future generations can enjoy the benefits Earth provides, which is the production of sufficient quantities of healthy food on the soils with preserved natural fertility.

Awareness of the need for sustainable development is already present to a centrian degree. Therefore, it is necessary to use all of the scientific and professional potential to create appropriate research programs and the implementation of those results in practice.

\section{Reference}

Balmford A., Amano T., Bartlett H., Chadwick D., Collins A., Edwards D., Field R., Garnsworthy P., Green R., Smith P., Waters H., Whitmore A., Broom D.M., Chara J., Finch T., Garnett E., Gathorne-Hardy A., Hernandez-Medrano J., Herrero M., Hua F., Latawiec A., Misselbrook T., Phalan B., Simmons B.I., Takahashi T., Vause J., Ermgassen E., Eisner, R. (2018). The environmental costs and benefits of high-yield farming. Nature Sustainability, 1/9: 477 DOI: 10.1038/s41893-0180138-5.

Bašić F. (1994). Klasifikacija oštećenja tala Hrvatske. Agronomski glasnik, 3-4: 291310.

Basic F. (2013). The Soils of Croatia. World Soil Book, Springer, doi: 10.1007/97894-007-5815-5.

Basic F. (2017). Soil Science in Face of New Challenges: Quo Vadis Soil Science? Food Science and Nutrition Technology, 2/3: 000126.

Blasi E., Passeri S., Galli F.A. (2016). An ecological footprint approach to environmental - economic evaluation of farm results. Agricultural Systems, 145: 7682. https://doi.org/10.1016/j.agsy.2016.02.013

Carter, J.G., Cavan, G., Connelly, A., Guy, S., Handley, J., Kazmierczak, A. (2015). Climate change and the city: Building capacity for urban adaptation. Progress in Planning, 95: 1-66. Online: http://dx.doi.org/10.1016/j.progress.2013.08.001

Cowie A.L., Orr B.J., Castillo Sanchez V.M., Chasek P., Crossman N.D., Erlewein A., Louwagie G., Maron M., Metternicht G.I., Minelli S., Tengberg A.E., Walter S., Welton S. (2018). Land in balance: The Scientific conceptual framework for Land Degradation Neutrality. Environmental Science and Policy, 79: 25-35, https://doi.org/10.1016/j.envsci.2017.10.011

Clark M., Tilman D. (2017). Comparative analysis of environmental impacts of agricultural production systems, agricultural input efficiency, and food choice. Environ. Res. Lett. 12: 064016.

Dudeja P., Singh A. (2017). Food safety issues related to plant foods at farms. Chapter in book: Food safety in the 21st Century. p. 179-191. 
Gomiero T. (2016). Soil degradation, Land Scarcity and Food Security: Reviewing a Complex Challenge. Sustainability, 8/3:281: https://doi.org/10.3390/su8030281

Kanianska R. (2016). Agriculture and Its Impact on Land-Use, Environment, and Ecosystems Services. In book: Landscape Ecology — The Influences of Land Use and Anthropogenic Impacts of Landscape Creation, DOI: 10.5772/63719.

Kisić I. (2014). Introduction to Organic Agriculture. Manualia Universitatis Studiorum Zagrabiensis. p. 340.

Kisić I. (2015). Remediation of soils affected by floods. 50th Croatian \& 10th International Symposium on Agriculture. Opatija.

Kisić I. (2019). Environmental aspects of open space fire. 54th Croatian \& 14th International Symposium on Agriculture, Vodice.

Kisić I. (2018). Urban Agriculture. Manualia Universitatis Studiorum Zagrabiensis. Zagreb, p. 311.

Kisic I., Zgorelec, Z., Percin, A. (2018). Soil treatment engineering. Chapter in book: Environmental engineering - Basic principles. Publisher: De Gruyter, p. 277316. https://doi.org/10.1515/psr-2016-0124

Lal R. (2004). Soil Carbon Sequestration Impacts on Global Climate Change and Food Security. Science, 304: doi: 10.1126/science.1097396

Lal R. (2014). Managing Terrestrial Carbon in a Changing Climate. In: Soil Security for Ecosystem Management, Springer. Briefs in Environment, Security, Development and Peace, p. 1-18.

Mirsal I.A. (2008). Soil Pollution - Origin, Monitoring \& Remediation. Springer, p. 312.

Montgomery D.R. (2012). Dirt - The Erosion of Civilizations. University of California Press, p. 285.

Pereira L., Wynberg R., Reis Y. (2018). Agroecology: The Future of Sustainable Farming? Environment: Science and Policy for Sustainable Development, 60:4, 4-17: https://doi.org/10.1080/00139157.2018.1472507

Sheibani S., Ahangar A.G. (2013). Effect of tillage on soil biodiversity. Journal of Novel Applied Sciences. 2/8: 273-281.

Sklenicka P., Janeckova Molnarova K., Salek K., Simova P., Vlasak J., Sekac P., Janovska V. (2015). Owner or tenant: Who adopt better soil conservation practices? Land Use Policy, 47: 253-261. http://dx.dpi.org/10.1016/j.landusepol.2015.04.017

Stern N. (2006). The Stern Review on the Economics of Climate Change. Online: http://mudancasclimaticas.cptec.inpe.br/ rmclima/pdfs/destaques/sternreview_report_complete.pdf

Varallyay G. (2007). Soil Resilience - Is soil renewable natural resources? VI. AlpsAdria Scientific Workshop. Obervellach Austria, p. 1277-1284, doi: 10.1556/ CRC.35.2007.2.278.

Virto I., Imaz M.J., Fernandez-Ugalde O., Gartzia-Bengoetxea N., Enrique A., Bescansa P. (2015). Soil degradation and Soil Quality in Western Europe: Current Situation and Future Perspectives. Sustainability 7: 313-365, https://doi.org/10.3390/ su7010313 
Wiesmeier M., Urbanski L., Hobley E., Lang B., von Lützow M., Marin-Spiotta E., van Wesemael, Rabot E., Ließ M., Garcia-Franco N., Wollschläger U., Vogel H.J., Kögel-Knabner I. (2019). Soil organic carbon storage as a key function of soils - A review of drivers and indicator at various scales. Geoderma, 333: 149162. https:// doi.org/10.1016/j.geoderma.2018.07.026 